Ivonne Pötschke*

\title{
A Felt Truth: Value Congruence in Family Firms**
}

\section{Abstract}

Family firms are known for having a strong culture and shared values, which arise from the ways in which family traditions and dynamics influence the business. Value congruence is known for having positive effects on employees' affective commitment, which is strongly connected to organisational performance. Thus, one can assume that a strong family influence on a business entails strong congruency between employees' and firms' values. To explore this topic in more depth, the present paper employs theoretical strands from family business research and person-organisation-fit theory.

To examine the relationship between family influence, value congruence and their effect on affective commitment, this study conducted an online survey among 15 family firms that were categorized according to their family influence. The paper compared firms with weak and strong family influence in terms of employees' value congruence and their affective commitment, as well as considered potential influencing factors such as leadership, management stewardship, and tenure. Different methods were used to analyse the data. The findings indicate that family firms with a strong family influence have higher levels of perceived value congruence and affective commitment among employees.

Keywords: organisational theory, social capital, family firms, value research

(JEL: D23, E71, L25, Z19)

\section{Introduction}

Family businesses are - as the name implies - distinguished by their unique interplay of family and business (Sanchez-Famoso, Maseda, \& Iturralde, 2017; Tagiuri \& Davis, 1996; Zellweger, Eddleston, \& Kellermann, 2010). By combining the family's emotional system with the rationality and efficiency of the economic system, such firms become different social systems with their own goals and values (Simon, 2002; Zimmermann, 2012). Researchers agree that, through this interplay, family firms acquire special resources. These specific resources (Habbershon \& Williams, 2003; Klein et al., 2005) manifest through corporate governance (e.g., ownership, control rights, generation succession) and cultural factors. Cultural fac-

* Ivonne Pötschke, Helmut Schmidt University/University of the Federal Armed Forces Hamburg, Germany. E-Mail: ivonne.poetschke@gmail.com

** Date submitted: May 13, 2019

Revised version accepted after double-blind review: January 31, 2020 
tors have an especially powerful influence over family businesses, as they contain a long-term vision for the family firm's survival and performance (Duh et al., 2010; Denison et al., 2004; Jimenez et al., 2015; Klein et al., 2005; Nicholson, 2008; Rau, Schneider-Siebke, \& Günther, 2019; Vallejo, 2008). Specifically, shared values reinforce the strength of an organisational culture, which can then influence employees' retention and thereby bolster the firm's success (Ashfort \& Mael, 1989; Denison et al., 2014; Gordon \& DiTomaso, 1992; Lavelle et al., 2009; Meyer, Becker, \& Van Dick, 2006; Meyer \& Herscovitch, 2001; Riketta, 2008; Sackmann, 2011; Vandenberghe, Bentein, \& Stinglhamber, 2004).

The performance of family firms has been a widely discussed topic in family business research. Many studies have demonstrated a positive relationship between family influence and firm performance (Rutherford et al., 2008). Most previous studies have focused strongly on financial performance criteria. However, the inclusion of the socioemotional-wealth perspective has broadened this performance view, indicating that family firms strive for different goals compared with non-family firms (Berrone, Cruz, \& Gomez-Mejia, 2012). Consequently, their performance measures may extend beyond financial criteria. However, there remains an open question about which cultural factors affect a family firm's performance and how. One of the most prominent performance indicators in organisational research is affective commitment (Meyer, Stanley, Jackson, McInnis, Maltin, \& Sheppard, 2012). Person-organisation-fit theory (PO-fit) proposes that there is a positive relationship between employees' retention and the congruency of individual and organisational values (i.e., value congruence). It is now widely accepted in human resource and organisational behaviour research that attracting and retaining employees is easier if there is value congruence between employees and the organization (Cable \& Judge, 1996; Cable \& DeRue, 2002; Edwards \& Cable, 2009; Kooji \& Boon, 2018; KristofBrown, Zimmermann, \& Johnson, 2005; Lajoie, Boudrias, Rousseau, \& Brunelle, 2017). However, the most recent applications of general human resource (HR) issues in the field of family business research have demonstrated that the heterogeneity and complexity of family firms create specific difficulties for implementing these general HR practices (Eddleston et al., 2018; Gomez-Mejia et al., 2018; Mullins, 2018). Special studies on PO-fit in family business research remain scarce to date. Hauswald et al. (2016) are the only ones so far to address PO-fit in family firms, finding that job seekers with a conservative value orientation are more attracted to family firms than those with self-enhancement values. Likewise, Rau et al. (2019) underlined the importance of values in family business research by explaining that family firms' heterogeneity results from value differences. Thus, there is a strong need to more deeply explore family firms' values (Payne, 2018; Rau et al., 2019).

Despite a large amount of general research on value congruence, there is a gap in the current person-organisation-fit and family business literature in terms of individual characteristics that might influence fit perceptions (Hauswald et al., 2016; Kidwell et al., 2018). Thus, this paper analyses the relation between family influ- 
ence and value congruence, and how this potential relation affects employees' affective commitment.

Accordingly, the paper addresses three gaps in the literature. First, the paper focuses on the perspective of (experienced) employees instead of students' hypothetical assessments of values (Hauswald et al., 2016; O'Reilly \& Chatman, 1989). Although previous research has studied the attractiveness of family firms for job seekers (Hauswald et al., 2016) or top management (Harsch \& Festing, 2019), this paper contributes to the existing literature by focusing on employees as new a target group. Thereby, the study answers a criticism in the PO-fit literature that most studies have been conducted with student samples (Carless, 2005). By considering employees' perspectives, the paper also follows current work in value congruence research that focuses on individual characteristics (Hauswald et al., 2016). Moreover, value congruence was operationalized in two ways: namely, a perceived and calculated fit measure. This operationalization broadens research on value congruence, as previous studies have largely focused solely on perceived value congruence (Amos \& Weathington, 2008; Lajoie et al., 2017). Thereby, the paper contributes to exploring the heterogeneity of family businesses by adding values as a further differentiation criterion (Rau et al., 2019).

Second, the study analyses employees' affective commitment as a performance criterion for family firms. Previous family business research has extensively compared the financial performance of family and non-family firms, highlighting the formers' higher profit margins, faster growth rates, more stable earnings, and lower dividend rates (Dyer, 2018; O’Boyle, Pollack, \& Rutherford, 2012; Wagner, Block, Miller, Schwens, \& Xi, 2015). Previous research has demonstrated that employees with high affective commitment show higher work performance (Cooper-Hakim \& Viswesvaran, 2005; Meyer et al., 2012; Riketta, 2002). Thus, analysing affective commitment as a non-economic performance goal of family firms contributes to the socioemotional-wealth perspective as well as the general discussion of performance in family firms (Berrone, Cruz \& Gomez-Mejia, 2012; Dyer, 2018).

Third, by considering various potentially influencing factors (leadership -behaviour, stewardship of management, tenure of leader-member relationship), the paper contributes to the call for considering conditional factors that influence family firms' performance (Dyer, 2018).

\section{Theoretical Background}

Conceptually, this paper builds on two theoretical approaches often applied in family business research to explain the relationship between family influence and employees' value congruence: social capital and stewardship theory (Melin, Nordqvist, \& Sharma, 2013). Both concepts are enriched with PO-fit theory from organisational value research (Chatman, 1989; Edwards \& Cable, 2009; Kristof, 1996; Kristof-Brown et al., 2005; Verquer et al., 2003). Given these three theoretical 
strands, the current paper is in line with recent calls for using multidisciplinary approaches to explore the nature of family businesses (Payne, 2018). The following section briefly outlines the theoretical background and includes the definition of key terms in this paper.

\section{The Influence of Family on Business}

There is not one family business theory, but rather various theories addressing special phenomena in family firms (Rau et al., 2018). As a result, there is an open question about how to appropriately measure family influence in family business research. However, there is no general operationalization for measuring family influence (Astrachan et al., 2002; Rau, Astrachan, \& Smyrnios, 2018). The most influential proposal for measuring family influence remains the F-PEC scale (Astrachan et al., 2002, Rau et al., 2018; Frank, Kessler, Rusch, Suess-Reyes, \& WeismeierSammer, 2017). The F-PEC scale measures the influence of family on business based on three measurement dimensions: power, experience and culture. Thus, the F-PEC scale aligns with the call for multi-dimensional measurements in the field (Astrachan et al., 2002).

Despite having inspired the family business research community to examine these three dimensions, the F-PEC scale is not without criticism (Carr, Massis, Pearson, 2018; Frank et al., 2017). The main criticism is that the F-PEC measures the potential influence in terms of percentages of family members in ownership, management or control. This measurement captures the potential, but not the actual family influence (Frank et al., 2017; Holt et al., 2010; Rutherford et al., 2018). Although the F-PEC claims to integrate both the involvement and the essence approaches, it focuses more on the former and (family's involvement) and fails to capture the latter (the essence of a family firm) (Rutherford et al., 2008). Recent research on defining family firms has concentrated on the essence of a family firm: for instance, by emphasizing values as a differentiating factor (Rau, Schneider-Siebke, \& Günther, 2019), given that values guide individual behaviour (Schwartz, 1992) and thereby capture the essence of a family firm (Chua et al., 1999).

From a methodological perspective, the F-PEC is used as a single-respondent measurement, which is not well suited for measuring the cultural dimension within the F-PEC scale. Organisational culture research strongly emphasizes that culture is a collective phenomenon created by all members of the organisation instead of a single-respondent measurement by the management of the firm (Denison et al., 2014; Schein, 1985). Considering these limitations, this paper offers an employee-based approach for measuring values as a means of investigating a family firm's culture and, by extension, its essence. 


\section{Social Capital Theory}

Social capital theory considers social relations to be a particularly prevalent resource in family firms (Cabrera-Suarez et al., 2015; Nahapiet \& Ghoshal, 1998; Pearson et al., 2008; Sorenson, 2013). Social capital establishes cohesion and trust, which then enables cooperation in the firm by subordinating individual interests to the collective (Adler \& Kwon, 2002; Arregle et al., 2007; Leana \& van Buren, 1999). When organisations possess resilient and generalized trust, they do not need to rely on strict monitoring and controlling mechanisms (Chrisman, Chua, Kellermanns, \& Chang, 2007), which has the collateral effect of making cooperation more efficient. In short, social capital supports organisational success (Leana \& van Buren, 1999; Pearson et al., 2008) and constitutes a widely accepted advantage of family firms.

Family business research argues that family firms' higher social capital stems from the relationship quality of family members. Family relationships are grounded in shared values, a common history, and frequent interaction (Herrero, 2018; Pearson \& Marler, 2010; Zellweger, Kellermanns, Eddleston, \& Memili, 2012), which collectively produce a type of trust that is stronger than the trust between non-family members (Davis et al., 2010; Pearson et al., 2008; Sundaramurthy, 2008). Trust is regarded as "a psychological state comprising the intention to accept vulnerability based upon positive expectations of the intentions or behaviour of another" (Rousseau et al., 1998). In this understanding, trust is a precondition for cooperation and an important organising principle for family firms (Eddleston et al., 2010; Herrero, 2018). Family members integrate their understanding of trust in business life by building a culture of trust within the firm (Baron, 2008; Morris et al., 2010). This sense of trust is further cemented by the family assuming a long-term perspective and anchoring themselves in the local community (Sequeira et al., 2007; Sorenson, 2013). Consequently, family firms have advantages that arise from the sources and evolution of trust.

\section{Stewardship Theory}

Previous research has highlighted that stewardship management is prevalent in family firms and fosters organisational performance (Davis, Allen, \& Hayes, 2010; Eddleston \& Kellermanns, 2007; Eddleston, Kellermanns, \& Zellweger, 2012; Madison, Kellermanns, \& Munyon, 2017; Vallejo, 2009). Stewardship theory argues that managers in family firms prioritize collective and altruistic interests ahead of their own (Breton-Miller \& Miller, 2009; Davis et al., 1997; Eddleston et al., 2012; Herrero, 2018). In contrast to managers of non-family firms, who are mainly motivated by financial results, stewardship managers in family firms strive to fulfil a social purpose (Le Breton Miller \& Miller, 2015). Because of the influence, these managers have on the business and their employees, family stewards are often associated with a transformational leadership style, which seeks to promote a collective 
identity by influencing followers' values (Campbell et al., 2008; Conger et al., 2000; Howell \& Shamir, 2005).

\section{Value Congruence}

Person-organisation-fit theory (PO-fit) is a sub-domain of person-environment-fit theory, which is an umbrella theory that analyses the "compatibility between an individual and a work environment that occurs, when their characteristics are well matched" (Kristof-Brown et al., 2005, p. 281). PO-fit research follows the tradition of the attraction-selection-attrition paradigm (Byrne, 1971; Schneider, 1987), which argues that individual organisational behaviour results from the interaction between the individual and the organisation (Argyris, 1957). These interactions are driven by values - specifically, the alignment of values between individual and firm (i.e., value congruence; Amos \& Weathington, 2008). Psychological value research sees values as stable and trans-situational principles that influence and guide individual thinking, feeling and behaviour (Rokeach, 1973; Schwartz, 1994). But this same understanding scales up to organisations, as underlined by previous research that applied Schwartz's basic values framework to the workplace (Borg, Groenen, Jehn, Bilsky, \& Schwartz, 2011; De Clercq, Fontaine, \& Anseel, 2008; Ros, Schwartz, \& Surkiss, 1999). Because values are relatively stable, directly comparable, and highly relevant at both the individual and organisational level (Cable \& Judge, 1997; Kristof-Brown et al., 2005), they are a key emphasis in PO-fit theory (Werbel \& DeMarie, 2005) and the most frequent operationalization of PO-fit (Chatman, 1989; Kristof-Brown et al., 2005).

This paper follows the organisational culture concept of Schein (1995), which considers values as essential for understanding organisational culture due to their guiding function for individual behaviour of organisational members (Denison et al., 2014; Meglino \& Ravlin, 1998; O’Reilly et al., 1991; Schein, 1995; Dyer, 1986). Schein's (1995) multi-level construct, which provides a framework for understanding how values translate into behaviour, covers three levels: assumptions, values and behaviour. The first level, assumptions, encompasses those beliefs that individuals take for granted and may even lack awareness of having. Values constitute the second level: Influenced by basic assumptions, they represent underlying global beliefs about desirable end states or behaviour. Behaviour, then, is the visible artefact at the top level of this framework, a reflection of the underlying cultural levels. In this model, values are an essential part of understanding and changing organisational culture (Meglino \& Ravlin, 1998; O’Reilly et al., 1991).

Research on value congruence seeks to explore how value congruence influences employees' work attitudes. Previous research established affective commitment as a prominent indicator for positive work attitudes (Meyer at al., 2012). In this context, value congruence is seen as an indicator for greater affective commitment (Chatman, 1989; Edwards \& Cable, 2009; Kristof, 1996; Kristof-Brown et al., 
2005; Verquer, Beehr, \& Wagner, 2003). Importantly, affective commitment is positively associated with organisational performance (Edwards \& Cable, 2009; Hofmann \& Woehr, 2008; Kristof-Brown et al., 2005; Verquer et al., 2003). To measure the impact of value congruence, many studies rely on the construct of organisational commitment, which is seen as "the relative strength of an individual's identification with and involvement in a particular organisation" (Mowday, Steers, \& Porter,1979). Therefore, this paper also adopts this well-established indicator of organisational performance to consider the impact of value congruence in the unique domain of family firms (Stanley \& Meyer, 2016).

\section{Hypothesis Development}

In family firms, values have a powerful impact because value orientations arise from family history and provide the foundation for a longstanding family identity, which is transferred from generation to generation (Fletcher, Melin, \& Gimeno, 2012; Pötschke, 2018; Rau et al., 2019; Sorenson, 2014). Because family members often hold important positions in the firm, they act as cultural role models who translate the family's values into organisational values (Ling, Simsek, Lubatkin, \& Veiga, 2008; O’Reilly, Caldwell, Chatman, \& Doerr, 2014; Vallejo, 2009); in this way, their value orientations can have a significant impact on the business for generations (Duh, Belak, \& Milfelner, 2010; Parada \& Dawson, 2017; Sorenson, 2013; Zwack, Kraiczny, von Schlippe, \& Hack, 2016). This mechanism becomes even stronger if several family members act as role models, in line with transformational leadership research (Brown \& Trevino, 2009; Hoffmann, 2011; Howell \& Avolio, 1993) and organisational culture research (Sackmann, 2011; Schein, 1995). We know from the leadership literature that role modelling influences employees' value orientations (Lajoie et al., 2017).

To provide an overview of chosen constructs and better understand their relationships, a model was drawn to introduce relevant construct for hypothesis development (Figure 2). The overall assumption is that the stronger the influence of the family (and their values) in the company, the stronger the sense of community among employees (as expressed by value congruence) and the higher the degree of bonding between employees and the firm (as operationalized by affective commitment). 


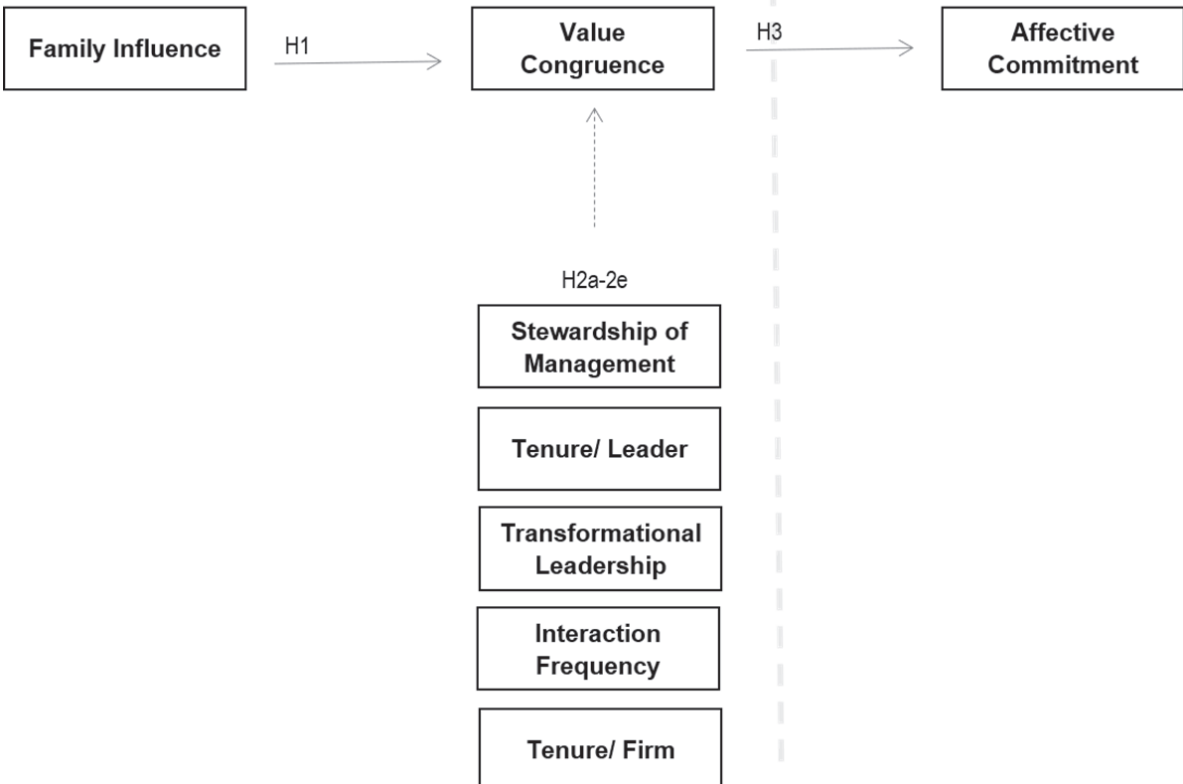

Figure 1. Model illustrating hypothesis development.

Thus, this paper assumes that a strong family identity - supported by family members who act as role models - positively influences employees' value congruence. The paper considers the number of family members working in the firm, and the number of generations in existence as an indicator of family tradition and thus cultural strength. The measures section will describe the proposed operationalizations of family influence and value congruence in greater detail. The first hypothesis is the following:

H1: Employees' (perceived/ objective) value congruence is higher in firms with a strong family influence.

Family influence is not only characterized by the number of family members in the firm, but also by the quality of their relationships. Familial relations are determined by trust, which arises from kinship and shared values. Family members tend to have stronger relationships as a result of interacting more often, both formally and informally, than non-family executives. This interaction frequency further promotes trust among family members (Herrero, 2018), which is then extended to non-family members and facilitates social capital in the firm. Consequently, social capital cultivated within the family is transferred into the business, and vice versa. Put simply, the organisational culture of a family firm is influenced by the transmission of family social manners, expectations and values (Sorensen et al., 2009). This process 
is bolstered by more family members assuming an active role in the firm (Sorensen et al., 2013), and it is especially influential when family members occupy executive management positions, such as the CEO. Driven by family norms and values (Herrero, 2018), family firm executives (stewards) are motivated to establish a reputable and ongoing firm (Miller \& Le Bretton Miller, 2006), whose success provides the executive with socioemotional benefits (e.g., reputation, sustainability) (GomezMejia, Cruz, Berrone, \& De Castro, 2011).

Indeed, stewardship theory highlights that family firm CEOs behave as stewards of the firm by being supportive and acting as persons of trust (Block, 1993; BretonMiller \& Miller, 2009; Arregle et al., 2007; Dirks \& Ferrin, 2002; Eddleston et al., 2012). If the CEOs pursue collective goals, they promote a sense of collectivity and trust and therefore foster value congruence among employees. Thus, it is assumed that:

H2a: There is a positive relationship between stewardship of management and employees' (perceivedl objective) value congruence.

Additionally, the analysis incorporates several variables that mainly reflect the intensity of the leader-follower relationship, which should have a positive effect on value congruence. Previous research demonstrates that the relationship between a leader and follower influences the value congruence between them, with the alignment becoming stronger as their interactions become longer and more frequent (Grean \& Uhl-Bien, 1995; Krishnan, 2005). The leadership literature points out that transformational and charismatic leadership styles have a positive effect on employees' value congruence (Brown \& Trevino, 2009; Hoffmann, 2011; Howell \& Avolio, 1993). If employees regard their leader as a role model, then their values become congruent with the leaders' expressed values (Brown \& Trevino, 2009). Presumably, this process aligns the employees' values with those of the firm, since executives typically exemplify the firm's values. Relatedly, research has continually found that transformational leadership is integral to employees' affective commitment (Avolio et al., 2004; Banks et al., 2016; Lajoie et al., 2017; Podsakoff et al., 1996). For this reason, the present study transfers expected relationships from general leadership research to the field of family firms and integrates transformational leadership as an additional control variable. In formal terms:

H2b: There is a positive relationship between the degree of transformational leadership and employees' (perceivedl objective) value congruence.

H2c: There is a positive relationship between employees' tenure with their supervisor and their (perceived/ objective) value congruence.

H2d: There is a positive relationship between employees' interaction with their management and their (perceived/ objective) value congruence. 
H2e: There is a positive relationship between employees' interaction with their supervisor and their (perceived/ objective) value congruence

H2f: There is a positive relation between employees' tenure with the company and (perceived/ objective) value congruence.

Affective commitment is considered one of the strongest outcome variables in POfit literature and is a known performance driver from the leadership and organisational culture literature (Avolio, Zhu, Kho, \& Bhatia, 2004; Vandenberghe, Bentein, \& Stinglhamber, 2004; Verquer, Behr, \& Wagner, 2003). Various meta-analyses have identified positive relationships between affective commitment and various work attitudes. Thus, employees with a high affective commitment are less likely seek other jobs, as well as show higher levels of attendance and organisational citizenship behaviour, and thereby higher work performance (Mathieu \& Zajac, 1990; Tett \& Meyer, 1993; Meyer, Stanley, Herscovitch, \& Topolnytsky, 2002, Riketta, 2002; Cooper-Hakim \& Viswesvaran, 2005; Stanley \& Meyer, 2016). Affective commitment, which has the strongest binding effect of the three commitment dimensions, involves an individual's emotional attachment to and identification with the organisation (Allen \& Meyer, 1990; Cooper-Hakim \& Viswesvaran, 2005; Meyer et al., 2002; Meyer et al., 2006; van Dick, 2004).

Furthermore, there seems to be a clear, positive relationship between affective commitment and value congruence (Boxx et al., 1991; Finegan, 2000; Meglino, Ravlin, \& Adkins, 1989; Rosete, 2006). Meyer et al. (2012) found in their meta-analysis that affective commitment positively correlates with a collectivist value orientation and negatively with an individualistic value orientation. This leads to the following hypothesis:

H3: There is a positive relationship between employees' (perceived/ objective) value congruence and their affective commitment.

\section{Methods}

\section{Sampling and Data Collection}

The sampled family firms were selected based on ownership, size, industry sector and region. First, the study focused on firms where the owner was a family member and active in the business (Klein et al., 2005). Second, the study focused on smalland medium-sized firms (SMEs) with fewer than 250 employees, as such firms represent the bulk of owner-managed family firms (Stiftung Familienunternehmen, 2014). Second, the study emphasized the logistics and manufacturing sector, as approximately $90 \%$ of manager-owned family firms occupy this domain (Stiftung Familienunternehmen, 2014). Third, regarding the region, the study concentrated on family firms in northern Germany to avoid confounding the results with a toolarge regional scope. 
In all of the sampled companies, the family held more than $50 \%$ of the shares and the number of employees was comparable (ranging between 20 and 250). Companies that met these criteria were approached via mailings and telephone calls. Ultimately, 15 family-run SMEs from the logistics or manufacturing industry took part in the survey. Nine companies provided complete responses and six firms only provided partial responses. The Results section (Table 2) presents an overview of the relevant variables and their statistical characteristics. The integrated data were used for regression analysis.

The data collection occurred between December 2017 and March 2018. Participants completed the questionnaire via an online survey. In contrast to a majority of studies on family firms, which follow a key informant approach (Kellermanns, Eddleston, Barnett, \& Pearson, 2008; Pearson et al., 2014), this paper chose a multiinformant approach and collected data from at least three employees in each firm.

In the first step, the management of participating firms answered the F-PEC questionnaire (Klein et al., 2005) to categorize their family business. Twenty-five firms completed the F-PEC questionnaire, although a majority did not return for the rest of the survey. Thus, 25 firms provided data on the family influence on a business (Table 1), but only 15 firms took part in the whole survey that included employees' ratings. For the ensuing survey, the firm's management shared an online participation link shared with all employees. Thus, potential employees came from different hierarchical levels and functions in the family firms. Variance analysis did not show significant relationships between position or function and the study variables.

\section{Measures}

The general questionnaire included the following sections: individual values, organisational values, perceived value congruence, transformational leadership, stewardship of management, affective commitment and demographic variables. All variables were measured on a 5 -point Likert scale. Tables 3 provides case numbers, mean values, standard deviations and bivariate correlations between relevant variables.

\section{Family Influence}

This paper defined family influence with two criteria: first, family members having a position in the firm and, second, the generation of the family business. These two criteria are of specific importance for the research question since family members determine the firm's value orientations, and those values are passed through and anchored from generation to generation (Eddleston, 2008; Schein, 2010; Sharma, 2004; Zwack, Kraiczny, von Schlippe, \& Hack, 2016). Recent family business research indicates that generational transfer highly determines the amount of family influence (Daspit, Holt, Chrisman, \& Long, 2016). These two criteria formed the 
basis of a family influence variable that was used to operationalize the construct (Table 1).

\section{Value Congruence}

The value congruence literature offers two strands of operationalization: direct (objective value congruence) or indirect (perceived value congruence) measurement (Kristof, 1996). The former measures the degree of difference between a variable describing the individual and a variable describing the organisation (Cable \& DeRue, 2002; Judge \& Cable, 1997). The latter includes a self-description of the individual and the organisation and then measures the perceived congruence (Cable \& DeRue, 2002; Edwards \& Billsberry, 2010).

This paper utilized both approaches. First, perceived value congruence was measured with a validated three-item scale (with a Cronbach's alpha of 0.92 ; Cable \& DeRue, 2002). Second, objective value congruence was computed as a PO-fit index per participant by calculating the difference between each participant's ratings of individual and organisational values. The study is not concerned with whether the value is positive or negative, but rather the absolute difference between values. For both indices, the absolute differences for all participants were computed and summed together, and then interpreted as follows: the higher the differences, the higher the index and the lower the value congruence. To make interpretation easier, the index reversed the polarity of objective value congruence. The higher the fit between individual and organisational values, the higher the objective POF value.

The objective value congruence was based on previous work (Pötschke, 2019) that exposed 16 values for measuring value orientations in family firms. These values are:

- Being socially responsible

- Tolerance

- Loyalty

- Honesty

- Being competitive

- Being highly organised

- Performance orientation

- Results orientation

- Rules orientation

- Being analytical

- Attention to detail

- Focus on quality

- Risk taking

- Not being constraint by many rules

- Autonomy

- Informality

Figure 2. Measured value items 


\section{Affective Commitment}

Affective commitment was operationalized with six items from Felfe and Franke (2012). The items are: 1) I would be very glad to be able to spend my future working life in this company; 2) I do not feel emotionally attached to this company; 3) I am proud to be part of this company; 4) I feel a strong sense of belonging to my company; 5) I think that my values fit with those of the company. Cronbach's alpha for this construct was 0.81 .

\section{Stewardship of Management}

Stewardship of management was measured with Davis' Stewardship scale, which deviates from other stewardship measures by focusing on an employee's perspective rather than the view of top management (Davis et al., 2010; Zahra et al., 2008). The items are: 1) My organisation's leaders have initiatives that serve the company's interests more than their own; 2) I believe that my organisation's leaders have initiatives that are credible and attractive; 3) The leaders of my organisation take a long-term more than a short-term approach to business. Cronbach's alpha in this study was 0.67.

\section{Transformational Leadership}

To measure transformational leadership, the study used three subscales from the transformational leadership inventory based on Podsakoff et al. (1990). These are "Identifying and articulating a vision" (5 items), "Providing an appropriate model" (3 items) and "Fostering group goals" (4 items). These subscales represent the core of transformational leadership (Heinitz \& Rowold, 2007) and were thus used to build an appropriate scale. Cronbach's alpha for this construct was 0.922 .

\section{Density of Interaction With Supervisor/Management}

The following items were used to measure employees' interactions with their supervisor: What percentage of your working time do you have personal contact with your direct supervisor? What percentage of your working time do you have personal contact with your management? Both questions asked for an answer in years.

\section{Tenure With Supervisor/ Firm}

Tenure with the supervisor/company was measured with two single items: How long have you been employed at this company? How long have you been working with your supervisor? Again, respondents indicated the number of years for both questions.

\section{Data Analysis}

The central aim of this paper is to build measures for both family influence and value congruence. To build classes of family influence, a short questionnaire was sent to the management of 25 firms to measure hard facts about them. Based on re- 
sponses related to "active family members in the firm" and "generation of the firm" in the F-PEC questionnaire, a family index was computed for the 25 firms (Table 1). Based on the family index, three categories of family influence (weak, moderate, strong family influence) were built (Table 1), whereby this construct was treated as a categorical variable. Subsequently, all 15 family firms that participated in the second, more comprehensive survey were assigned to these three classes (see variable family influence (categorial), Table 1).

To illustrate differences in value preferences between firms with weak, moderate or strong family influence, an explorative analysis of data was done (Table 2). Due to the small case numbers for potential moderating variables, multivariate analysis could not be seriously applied for all research questions. In cases with an insufficient number of participants, the data analysis focused on bivariate analysis. For all variables, the striking correlations were considered (Table 4).

Several methodological approaches were used to analyse the effects of family influence on value congruence and affective commitment. First, a t-test for independent samples was applied to investigate whether there is a statistically significant difference between the means exhibited by family firms with weak versus strong family influence. To examine these mean differences, the variable family influence was recoded into a two-class variable (weak/ strong). To interpret the t-test results appropriately, the Levene test for variance homogeneity was conducted. Finally, regression analysis was used to calculate the relationship between family influence, value congruence and affective commitment.

\section{Results}

Table 1. Categorization of Family Influence (15 Firms Took Part in the Extensive Survey and Built the Basis for Further Analysis; Those 15 Firms Were Assigned to a Family Influence Category.)

\begin{tabular}{|c|c|c|c|c|c|c|c|}
\hline Firm & Employees & Founding & $\begin{array}{c}\text { Active } \\
\text { family } \\
\text { members }\end{array}$ & $\begin{array}{c}\text { Genera- } \\
\text { tion }\end{array}$ & $\begin{array}{c}\text { Family } \\
\text { Index }\end{array}$ & $\begin{array}{c}\text { Family } \\
\text { Influence } \\
\text { (Categorial) }\end{array}$ & $\begin{array}{c}\text { Number } \\
\text { of partici- } \\
\text { pating } \\
\text { employees }\end{array}$ \\
\hline 1 & 40 & 1983 & 2 & 2 & 2 & & \\
\hline 2 & 80 & 1970 & 2 & 2 & 2 & 2 & 5 \\
\hline 3 & 120 & 1986 & 1 & 1 & 1 & 1 & 9 \\
\hline 4 & 100 & 1946 & 3 & 2 & 2,5 & & \\
\hline 5 & 150 & 1974 & 4 & 2 & 3 & & \\
\hline 6 & 70 & 1834 & 2 & 4 & 3 & & \\
\hline 7 & 34 & 1983 & 1 & 1 & 1 & & \\
\hline 8 & 75 & 1971 & 3 & 2 & 2,5 & 3 & 6 \\
\hline 9 & 250 & 1876 & 1 & 1 & 1 & & \\
\hline 10 & 200 & 1922 & 1 & 3 & 2 & & \\
\hline
\end{tabular}




\begin{tabular}{|c|c|c|c|c|c|c|c|}
\hline Firm & Employees & Founding & $\begin{array}{c}\text { Active } \\
\text { family } \\
\text { members }\end{array}$ & $\begin{array}{c}\text { Genera- } \\
\text { tion }\end{array}$ & $\begin{array}{l}\text { Family } \\
\text { Index }\end{array}$ & $\begin{array}{c}\text { Family } \\
\text { Influence } \\
\text { (Categorial) }\end{array}$ & $\begin{array}{c}\text { Number } \\
\text { of partici- } \\
\text { pating } \\
\text { employees }\end{array}$ \\
\hline 11 & 150 & 1823 & 2 & 6 & 4 & & \\
\hline 12 & 50 & 1859 & 2 & 6 & 4 & 3 & 11 \\
\hline 13 & 200 & 1962 & 1 & 2 & 1,5 & & \\
\hline 14 & 100 & 2008 & 1 & 1 & 1 & & \\
\hline 15 & 20 & 2002 & 1 & 1 & 1 & 1 & 15 \\
\hline 16 & 50 & 1994 & 2 & 2 & 2 & 2 & 6 \\
\hline 17 & 106 & 1990 & 3 & 1 & 2 & 2 & 4 \\
\hline 18 & 15 & 1995 & 2 & 1 & 1,5 & 1 & 6 \\
\hline 19 & 240 & 1986 & 2 & 2 & 2 & 2 & 10 \\
\hline 20 & 230 & 1925 & 1 & 2 & 1,5 & 1 & 8 \\
\hline 21 & 145 & 1955 & 2 & 2 & 2 & 2 & 6 \\
\hline 22 & 65 & 1614 & 1 & 14 & 7,5 & 3 & 3 \\
\hline 23 & 20 & 1991 & 1 & 1 & 1 & 1 & 9 \\
\hline 24 & 120 & 1905 & 2 & 4 & 3 & 3 & 18 \\
\hline 25 & 210 & 1864 & 1 & 5 & 3 & 3 & 7 \\
\hline \multicolumn{3}{|c|}{ Mean } & 1,76 & 2,8 & 2,28 & & \\
\hline
\end{tabular}

Table 2. Mean Values Represent Perception of Value Orientation in Firms Based on Employees' Ratings

\begin{tabular}{|l|c|c|c|c|}
\hline & Relation & Performance & Autonomy & Accuracy \\
\hline $\begin{array}{l}\text { Strong Family Influence } \\
(\mathrm{N}(\text { employee level) =46) }\end{array}$ & 3,9 & 3,6 & 3,1 & 3,5 \\
\hline $\begin{array}{l}\text { Moderate Family Influence } \\
(\mathrm{N} \text { (employee level) =30) }\end{array}$ & 3,4 & 3,4 & 2,9 & 3,3 \\
\hline $\begin{array}{l}\text { Weak Family Influence } \\
(\mathrm{N}(\text { employee level) =47) }\end{array}$ & 3,2 & 3 & 2,9 & 3 \\
\hline
\end{tabular}

\section{Table 3. Descriptive Statistics of 15 firms}

\begin{tabular}{|l|c|c|c|c|c|}
\hline & N & Minimum & Maximum & Mean & $\begin{array}{c}\text { Standard } \\
\text { deviation }\end{array}$ \\
\hline Family Influence & 123 & 1.00 & 3.00 & 1.992 & 0.873 \\
\hline Perceived Value Congruence & 107 & 1.00 & 5.00 & 3.446 & 0.782 \\
\hline Objective Value Congruence & 114 & -28.00 & 0.00 & -9.645 & 5.310 \\
\hline Affective Commitment & 90 & 1.75 & 5.00 & 3.697 & 0.945 \\
\hline Stewardship & 55 & 2.00 & 5.00 & 4.067 & 0.710 \\
\hline Transformational Leadership & 62 & 2.00 & 5.00 & 3.435 & 0.705 \\
\hline Tenure employer (in years) & 85 & 0.0 & 30.0 & 6.053 & 6.039 \\
\hline Tenure supervisor (in years) & 69 & 0.0 & 30.0 & 6.652 & 6.1628 \\
\hline Interaction supervisor (in \%) & 69 & 1 & 96 & 24,10 & 29.835 \\
\hline Interaction management (in \%) & 41 & 1 & 20 & 4,78 & 3.870 \\
\hline
\end{tabular}




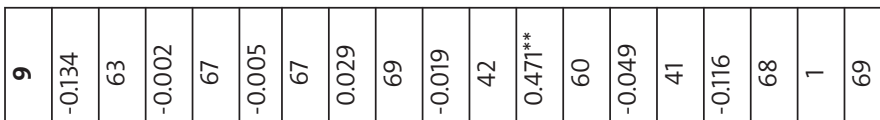

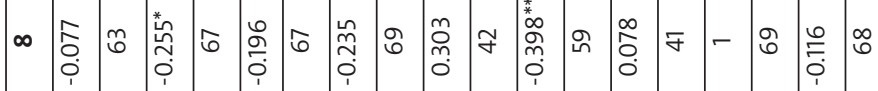

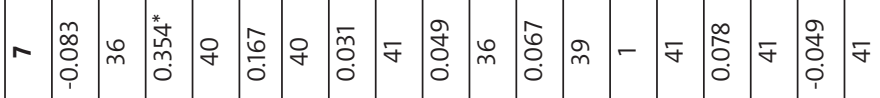

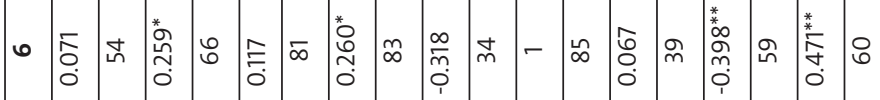

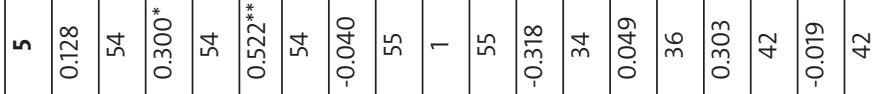

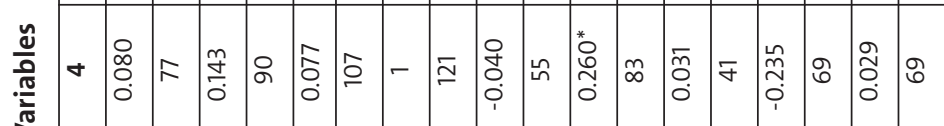

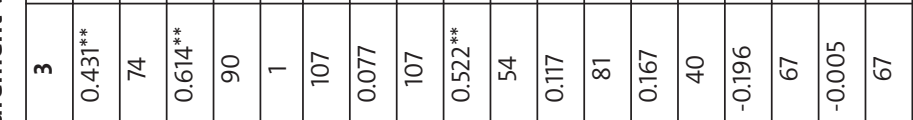

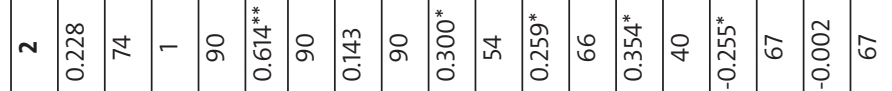

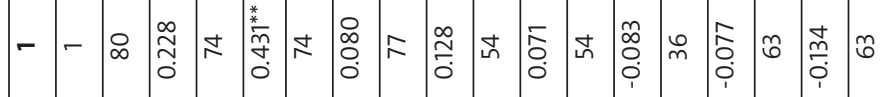

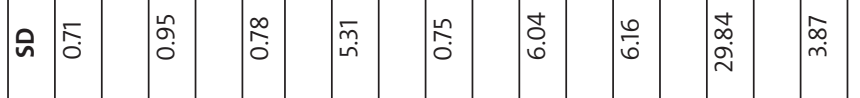

문

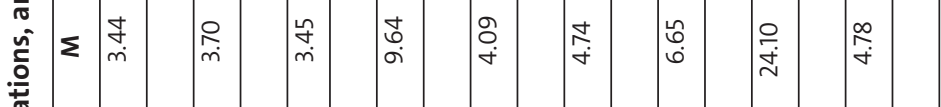

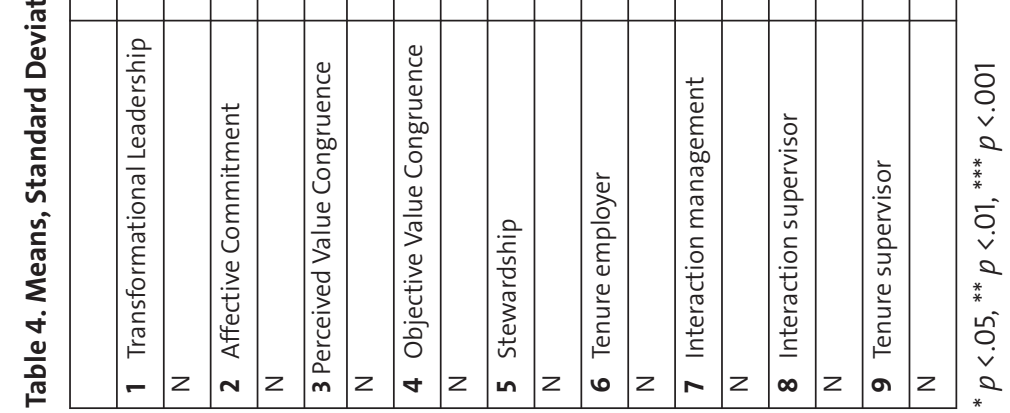


Focusing on the relations between family influence on business and value congruence, the results are as follows: After analysing the descriptive statistics (Table 3), ttests were computed with all variables (Table 5). The results underscore the notion that family firms with strong family influence have higher mean values for almost all variables than family firms with weak family influence (Tables 5 and 6). The differences in the means were significant for the following variables: perceived value congruence $(\mathrm{p}=0.002)$, affective commitment $(0.015)$, and stewardship (0.001). These findings support hypothesis 1 , which stated that there are higher levels of employees' value congruence in firms with a strong influence of family. However, the supposed relation was only confirmed for perceived value congruence and not for objective value congruence.

Table 5. Group Statistics for T-Test (Column Group: 1 = Weak Family Influence; $\mathbf{2}=$ Strong Family Influence); Variables That Were Excluded Due to Unequal Group Sizes Are Presented in Italics

\begin{tabular}{|l|c|c|c|c|}
\hline & Group & N & Mean & $\begin{array}{c}\text { Standard } \\
\text { deviation }\end{array}$ \\
\hline Perceived Value Congruence & 1 & 43 & 3.295 & 0.735 \\
\cline { 2 - 5 } & 2 & 35 & 3.810 & 0.697 \\
\hline \multirow{3}{*}{ Affective Commitment } & 1 & 26 & 3.637 & 0.824 \\
\cline { 2 - 5 } & 2 & 35 & 4.174 & 0.835 \\
\hline Objective Value Congruence & 1 & 46 & 10.009 & 5.667 \\
\cline { 2 - 5 } & 2 & 38 & 8.584 & 5.514 \\
\hline Tenure supervisor & 1 & 22 & 5.295 & 4.137 \\
\cline { 2 - 5 } & 2 & 18 & 8.889 & 9.259 \\
\hline \multirow{3}{*}{ Interaction supervisor } & 1 & 22 & 18.360 & 24.620 \\
\cline { 2 - 5 } & 2 & 18 & 30.670 & 36.746 \\
\hline Interaction management & 1 & 17 & 6.350 & 5.373 \\
\cline { 2 - 5 } & 2 & 4 & 4.000 & 0.816 \\
\hline Tenure employer & 1 & 38 & 6.053 & 5.259 \\
\cline { 2 - 5 } & 2 & 18 & 7.306 & 9.030 \\
\hline Stewardship & 1 & 17 & 3.608 & 0.784 \\
\cline { 2 - 5 } & 2 & 22 & 4.333 & 0.483 \\
\hline Transformational Leadership & 1 & 22 & 3.559 & 0.743 \\
\cline { 2 - 5 } & 2 & 30 & 3.499 & 0.738 \\
\hline
\end{tabular}


Table 6. T-Test Statistics for Examining Mean Differences for Employees From Firms With Weak Family Influence and Strong Family Influence (Significant Mean Differences Are Marked With *)

\begin{tabular}{|l|c|c|c|c|c|}
\hline & \multicolumn{2}{|c|}{ Variance homogeneity } & \multicolumn{3}{c|}{ T-test } \\
\hline & $\mathrm{F}$ & $\begin{array}{c}\text { Significance } \\
(\mathrm{p})\end{array}$ & $\mathrm{T}$ & $\mathrm{df}$ & $\begin{array}{c}\text { Significance } \\
(\mathrm{p})\end{array}$ \\
\hline $\begin{array}{l}\text { Perceived Value } \\
\text { Congruence }\end{array}$ & 0.495 & 0.484 & -3.149 & 76 & $0.002^{*}$ \\
\hline $\begin{array}{l}\text { Affective Value } \\
\text { Congruence }\end{array}$ & 0.070 & 0.793 & -2.500 & 59 & $0.015^{*}$ \\
\hline $\begin{array}{l}\text { Objective Value } \\
\text { Congruence }\end{array}$ & 0.331 & 0.567 & 1.161 & 82 & 0.249 \\
\hline Tenure supervisor & 19.975 & 0.000 & -1.527 & 22,520 & 0.141 \\
\hline $\begin{array}{l}\text { Interaction } \\
\text { supervisor }\end{array}$ & 8.643 & 0.006 & -1.215 & 28,652 & 0.234 \\
\hline $\begin{array}{l}\text { Interaction } \\
\text { management }\end{array}$ & 4.321 & 0.051 & 0.857 & 19 & 0.402 \\
\hline Tenure employer & 1.716 & 0.196 & 0.664 & 54 & 0.510 \\
\hline Stewardship & 3.385 & 0.074 & -3.562 & 37 & $0.001^{*}$ \\
\hline
\end{tabular}

Considering the relations between value congruence and affective commitment, the correlation analysis indicated a positive and significant correlation between perceived value congruence and affective commitment $\left(0.614^{* *}\right)$, thus supporting hypothesis 3 . However, the correlation between objective value congruence and affective commitment was not significant (0.143).

The correlation analysis of potential influencing factors showed the following results: There were significant correlations between perceived value congruence and transformational leadership $\left(0.431^{* *}\right)$ and stewardship of management $\left(0.522^{* *}\right)$. These results support hypotheses $2 \mathrm{a}$ and $2 \mathrm{~b}$. Objective value congruence only showed one moderate correlation with tenure at the employer $\left(0.260^{*}\right)$. Thereby, supporting hypothesis $2 \mathrm{f}$. The analysis showed no correlations between the other potential influencing factors of value congruence: interaction with management (hypothesis 2d), interaction with supervisor (hypothesis 2e), and tenure with supervisor (hypothesis 2c). Interestingly, most of these potential influencing factors have moderate correlations with affective commitment. Due to the small number of cases for potential moderating variables, it was not possible to conduct multivariate analysis at the firm level (Podsakoff, MacKenzie, \& Podsakoff, 2012; VanVoorhis \& Morgan, 2007).

However, a linear regression was conducted to predict employees' affective commitment based on value congruence. For these variables, employees' level - providing more number of cases. The results showed a significant relationship between perceived $\left(B=0.614^{* * *}\right)$ and affective commitment, but not between objective value congruence and affective commitment $(\beta=0.143$ (Table 7). In other words, if em- 
ployees' perceived value congruence increases, so do their affective commitment. Therefore, the regression analysis also supports hypothesis 3 .

Table 7. Regression Analysis Hypothesis 3: Standardized Beta Weights and Change in $\mathbf{R}^{2}$ Are Shown

\begin{tabular}{|l|c|c|c|}
\hline & \multicolumn{3}{|c|}{ Affective Commitment } \\
\hline & $\boldsymbol{B}$ & $\mathbf{R}^{\mathbf{2}}$ & $\mathbf{P}$ \\
\hline Perceived Value Congruence & $0.614^{* * *}$ & 0.377 & 0.000 \\
\hline Objective Value Congruence & 0.143 & 0.020 & 0.178 \\
\hline
\end{tabular}

${ }^{*} p<.05,{ }^{* *} p<.01,{ }^{* * *} p<.001$

Finally, those variables that had a strong relation with value congruence in correlation analysis were considered for further analysis: namely, transformational leadership and stewardship were admitted to a hierarchical regression analysis with perceived value congruence as the dependent variable. Both variables were examined as a predictor for perceived value congruence. The findings from hierarchical regression showed that stewardship has a stronger effect on perceived value congruence than transformational leadership. Transformational leadership was not confirmed as a significant influencing factor for perceived value congruence (Table 8).

Table 8. Regression Analysis: Model Summary and Coefficients Are Shown

\begin{tabular}{|l|l|l|l|l|l|l|}
\hline \multicolumn{7}{|c|}{ Model summary } \\
\hline & $R$ & $R^{2}$ & Adjusted R & Standard Error & $P$ & $\begin{array}{l}\text { Durbin- } \\
\text { Watson }\end{array}$ \\
\hline & 0.543 & 0.295 & 0.267 & 0.583 & & 1.43 \\
\hline
\end{tabular}

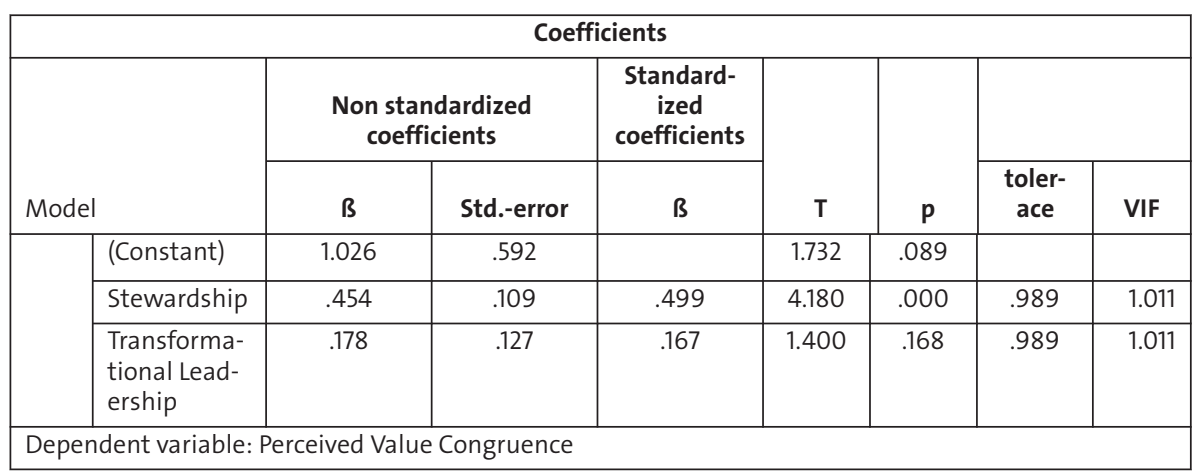

${ }^{*} p<.05,{ }^{* *} p<.01,{ }^{* * *} p<.001$

\section{Discussion}

This study produced the following key results: First, firms with strong family influence on the business show significantly higher values in perceived value congruence, 
stewardship of management and affective commitment (hypothesis 1). Second, only transformational leadership and stewardship of management showed significant correlations with perceived value congruence (hypothesis $2 \mathrm{a} / 2 \mathrm{~b}$ ). The results from the following hierarchical regression confirmed only stewardship as a significant explanatory factor for perceived value congruence. Third, the analysis underlined a significant and positive correlation between perceived value congruence and affective commitment (hypothesis 3). No significant results were found for objective value congruence in any analytical step, neither as a differentiating feature of firms with a strong family influence nor as an influencing factor for affective commitment. One explanation might be that objective value congruence as an actual measure does not provide sufficient findings when referring to the firm level. We know from organisational culture research that values differ between organisational subcultures due to their function (e.g., Sackmann, 2011; Schein, 1995). Thus, one employee might have a strong actual fit with the values of his/ her department, but no fit with the overall firm's values. This is in line with Edwards and Billsberry's (2010) finding that fit perceptions differ between different organisational levels, as well as strongly accords with Hauswald et al.'s (2016) finding that individuals with a collectivistic value are attracted to family firms because of a perceived overlap in value orientation, which is then projected on to the firm's management. In this view, a family firm's management might be regarded as a magnet of attraction.

Notably, the correlation analysis also demonstrated significant, positive relations between the stewardship of management and affective commitment. Thus, these results support previous findings that stewardship behaviour fosters family firms' performance (Eddleston \& Kellermanns, 2007; LeBretton Miller, \& Miller, 2015; Miller \& LeBretton Miller, 2006; Minichilli, Brogi, \& Calabrò, 2016). Interestingly, positive relationships were not found between objective value congruence and affective commitment. Moreover, the results showed that tenure with the employer and interaction frequency both had significant positive correlations with management and affective commitment. These findings support results from Kooij and Boon (2018), who demonstrated that tenure and integration in the firm foster perceived value congruence and employees' affective commitment. These employees with a high tenure possibly developed more a collectivistic than individualistic value orientation.

Bivariate analysis also highlighted a positive relationship between transformational leadership and stewardship of management with perceived value congruence (hypotheses $2 \mathrm{a} / 2 \mathrm{~b}$ ). These results underline the importance of management characteristics and accord with findings from Laijoe (2017) that emphasized value congruence as a substitute for transformational leadership styles. Thus, future research should investigate the potential moderating effects of interaction with management and tenure with the firm. Possible questions to be addressed regarding value congruence in family firms include: To what extent does tenure within the company moderate the relation between the family's influence on business and employees' 
value congruence? To what extent does the interaction frequency with management moderate the relation between employees' value congruence and commitment?

Although the regression results supported the assumed relation between affective commitment and both perceived value congruence and transformational leadership, the correlation analysis and t-test found no differences in transformational leadership between firms with weak and strong family influence. From a leadership research perspective, this result supports the commonly-known cause-effect relation between transformational leadership and value congruence with affective commitment but does not hint at differences in transformational leadership in relation to family influence. Thus, it is not necessarily the case that the leadership style might differ in family firms, but rather that other factors have an impact (e.g., stewardship of management). Thus, future research might examine leadership styles in family firms in greater detail (Rau et al., 2018).

Thus, family influence fosters employees' perceived value congruence and thereby strengthens family firms' identity. The findings highlighted the stewardship of management as a specific influencing factor. This finding underscores previous work stating that values - as a central cultural element - represent a success factor for family firms (Vallejo-Martos, 2011; Vallejo-Martos \& Puentas-Poyatos, 2014). More broadly, these results support the work of Hauswald et al. (2016), who found that more conservative individuals feel attracted to family firms. Interestingly, it is only employees' perceived (but not objective) value congruence that is higher in firms with a strong family influence. Moreover, regression analysis showed that only perceived value congruence can predict employees' affective commitment (hypothesis 3). This is in line with a meta-analysis in commitment research confirming a positive (negative) relation between affective commitment and a collectivistic (individualistic) value orientation (Meyer, Stanley, Jackson, McInnis, Maltin, \& Sheppard, 2012). By extension, employees with a strong sense of value orientation seem to be attracted to firms with a strong family influence. Thus, it is not their alignment with firms' values that bind them, but rather their assumption of an alignment. Finally, the positive effect of value congruence in family firms seems to be a self-fulfilling prophecy. This positive attribution might be a result of persuasive family firm communication (Krappe, Goutas, \& von Schlippe, 2011). This positive attribution mechanism also seems to work for management, as stewardship of management has a stronger effect than transformational leadership. A possible explanation is that the evaluation of management behaviour is a more subjective perception than the evaluation of one's leaders due to the former's greater distance.

Put simply, these results suggest that family influence might be more context-dependent, and that future research needs to consider both the firm environment and the individuals themselves to identify the variables that influence performance (Kosmidou \& Ahuja, 2019). On a related point, scholars should measure family firms' 
performance from a broader perspective by integrating further criteria, such as employees' turnover intention and job satisfaction.

Furthermore, this work contributes to research on stewardship by considering employees' ratings of the construct. Based on these indications, it would be interesting to more deeply analyse how stewardship of management affects employees' value congruence in family firms, which could offer a broader understanding of effective mechanisms like "familiness". Future research could also examine the characteristics and leadership styles of individual executives and their impact on employees' value congruence. Additionally, an interesting research topic would be to analyse different employee groups in a larger sample.

In sum, the results substantiate a recent call for analysing the conditional factors that influence family firms' performance (Dyer, 2018). The study underscores the notion that management characteristics can provide important conditional factors when evaluating performance.

\section{Limitations}

This paper features some limitations due to the small number of cases and a comparatively large number of missing values. Due to these deficiencies, multivariate analysis was rarely possible and the complex relations between variables could not be investigated. Due to the small number of cases in this study, an analysis based on different value types was not reasonable. Future research should concentrate on a value type-specific analysis of what influences performance criteria. Such a detailed analysis would strongly contribute to analysing heterogeneity in family firms (Rau et al., 2019). Moreover, the data collection could be marred by single-source bias, as the dependent and independent variables were collected from the same respondents (Podsakoff \& Organ, 1986). To avoid common rater bias, future research should collect predictor and outcome variable at different times (Podsakoff et al., 2012). Nonetheless, this study has presented fruitful conceptual considerations and examined several factors that influence the perceived value congruence of family firms.

\section{References}

Adler, P. S., \& Kwon, S. W. (2002). Social capital: Prospects for a new concept. Academy of Management Review, 27(1), 17-40.

Allen, N. J., \& Meyer, J. P. (1990). The measurement and antecedents of affective, continuance and normative commitment to the organization. Journal of Occupational Psychology, 63(1), 118.

Amos, E. A., \& Weathington, B. L. (2008). An analysis of the relation between employee-organization value congruence and employee attitudes. The Journal of Psychology, 142(6), 615-632.

Arregle, J. L, Hitt, M. A, Sirmon, D. G., \& Very, P. (2007). The development of organizational social capital: Attributes of family firms. Journal of Management Studies, 44(1), 73-95. 
Ashforth, B. E., \& Mael, F. (1989). Social identity theory and the organization. Academy of Management Review, 14(1), 20-39.

Astrachan, J. H., Klein, S. B., \& Smyrnios, K. X. (2002). The F-PEC scale of family influence: A proposal for solving the family business definition problem. Family Business Review, 15(1), 4558.

Avolio, B. J., Zhu, W., Koh, W., \& Bhatia, P. (2004). Transformational leadership and organizational commitment: Mediating role of psychological empowerment and moderating role of structural distance. Journal of Organizational Behavior: The International Journal of Industrial, Occupational and Organizational Psychology and Behavior, 25(8), 951-968.

Banks, G. C., McCauley, K. D., Gardner, W. L., \& Guler, C. E. (2016). A meta-analytic review of authentic and transformational leadership: A test for redundancy. The Leadership Quarterly, $27(4), 634-652$.

Baron, R. A. (2008). The role of affect in the entrepreneurial process. Academy of Management Review, 33(2), 328-340.

Berrone, P., Cruz, C., \& Gomez-Mejia, L. R. (2012). Socioemotional wealth in family firms: Theoretical dimensions, assessment approaches, and agenda for future research. Family Business Review, 25(3), 258-279.

Cable, D. M., \& Judge, T. A. (1997). Interviewers' perceptions of person-organization fit and organizational selection decisions. Journal of Applied Psychology, 82(4), 546-561.

Cabrera-Suárez, M. K., Déniz-Déniz, M. C., \& Martín-Santana, J. D. (2015). Family social capital, trust within the TMT, and the establishment of corporate goals related to nonfamily stakeholders. Family Business Review, 28(2), 145-162.

Campbell, S. M., Ward, A. J., Sonnenfeld, J. A., \& Agle, B. R. (2008). Relational ties that bind: Leader-follower relationship dimensions and charismatic attribution. The Leadership Quarterly, 19(5), 556-568.

Carless, S. A. (2005). Person-job fit versus person-organization fit as predictors of organizational attraction and job acceptance intentions: A longitudinal study. Journal of Occupational and Organizational Psychology, 78(3), 411-429.

Chrisman, J. J., Chua, J. H., Kellermanns, F. W., \& Chang, E. P. (2007). Are family managers agents or stewards? An exploratory study in privately held family firms. Journal of Business Research, 60(10), 1030-1038.

Cooper-Hakim, A., \& Viswesvaran, C. (2005). The construct of work commitment: Testing an integrative framework. Psychological Bulletin, 131(2), 241-259.

Crossan, M. M., \& Apaydin, M. (2010). A multi-dimensional framework of organizational innovation: A systematic review of the literature. Journal of Management Studies, 47(6), 1154-1191.

Daspit, J. J., Holt, D. T., Chrisman, J. J., \& Long, R. G. (2016). Examining family firm succession from a social exchange perspective: A multiphase, multistakeholder review. Family Business Review, 29(1), 44-64.

Davis, J. H., Allen, M. R., \& Hayes, H. D. (2010). Is blood thicker than water? A study of stewardship perceptions in family business. Entrepreneurship Theory and Practice, 34(6), 10931116.

Davis, J. H., Schoorman, F. D., \& Donaldson, L. (1997). Toward a stewardship theory of management. Academy of Management Review, 22(1), 20-47. 
Dirks, K. T., \& Ferrin, D. L. (2002). Trust in leadership: Meta-analytic findings and implications for research and practice. Journal of Applied Psychology, 87(4), 611-628.

Duh, M., Belak, J., \& Milfelner, B. (2010). Core values, culture and ethical climate as constitutional elements of ethical behaviour: Exploring differences between family and non-family enterprises. Journal of Business Ethics, 97(3), 473-489.

Dyer, W. G. (2018). Are family firms really better? Reexamining "examining the 'family effect' on firm performance”. Family Business Review, 31(2), 240-248.

Eddleston, K. A., Kellermanns, F. W., \& Kidwell, R. E. (2018). Managing Family Members: How Monitoring and Collaboration Affect Extra-Role Behavior in Family Firms. Human Resource Management, 57(5), 957-977.

Eddleston, K. A., Chrisman, J. J., Steier, L. P., \& Chua, J. H. (2010). Governance and trust in family firms: An introduction. Entrepreneurship Theory and Practice, 34(6), 1043-1056.

Eddleston, K. A., \& Kellermanns, F. W. (2007). Destructive and productive family relationships: A stewardship theory perspective. Journal of Business Venturing, 22(4), 545-565.

Eddleston, K. A., Kellermanns, F. W., \& Zellweger, T. M. (2012). Exploring the entrepreneurial behavior of family firms: Does the stewardship perspective explain differences? Entrepreneurship Theory and Practice, 36(2), 347-367.

Edwards, J. A., \& Billsberry, J. (2010). Testing a multidimensional theory of person-environment fit. Journal of Managerial Issues, 22(4), 476-493.

Edwards, J. R., \& Cable, D. M. (2009). The value of value congruence. Journal of Applied Psychology, 94(3), 654-677.

Felfe, J., \& Franke, F. (2012). Commit: Commitment-Skalen: Fragebogen zur Erfassung von Commitment gegenüber Organisation, Beruf, Tätigkeit, Team, Führungskraft und Beschäftigungsform; deutschsprachige Adaptation und Weiterentwicklung der Organizational commitment scale von Meyer und Allen. Göttingen: Hogrefe.

Finegan, J. E. (2000). The impact of person and organizational values on organizational commitment. Journal of Occupational \& Organizational Psychology, 73(2), 149-170.

Fletcher, D., Melin, L., \& Gimeno, A. (2012). Culture and values in family business: A review and suggestions for future research. Journal of Family Business Strategy, 3(3), 127-131.

Gomez-Mejia, L. R., Cruz, C., Berrone, P., \& De Castro, J. (2011). The bind that ties: Socioemotional wealth preservation in family firms. Academy of Management Annals, 5(1), 653-707.

Gomez-Mejia, L. R., Larraza-Kintana, M., Moyano-Fuentes, J., \& Firfiray, S. (2018). Managerial family ties and employee risk bearing in family firms: Evidence from Spanish car dealers. $\mathrm{Hu}$ man Resource Management, 57(5), 993-1007.

Gordon, G. G., \& DiTomaso, N. (1992). Predicting corporate performance from organizational culture. Journal of Management Studies, 29(6), 783-798.

Gottschalk, S., Niefert, M., Licht, G., Wagner, S., Hauer, A., Keese, D., \& Woywode, M. (2014). Die volkswirtschaftliche Bedeutung der Familienunternehmen: Aktualisierung 2014. Stiftung Familienunternehmen.

Graen, G. B., \& Uhl-Bien, M. (1995). Relationship-based approach to leadership: Development of leader-member exchange (LMX) theory of leadership over 25 years: Applying a multi-level multi-domain perspective. The Leadership Quarterly, 6(2), 219-247.

Habbershon, T. G., Williams, M., \& MacMillan, I. C. (2003). A unified systems perspective of family firm performance. Journal of Business Venturing, 18(4), 451-465. 
Hauswald, H., Hack, A., Kellermanns, F. W., \& Patzelt, H. (2016). Attracting new talent to family firms: who is attracted and under what conditions? Entrepreneurship Theory and Practice, 40(5), 963-989.

Harsch, K., \& Festing, M. (2019). Managing non-family talent: Evidence from German-speaking regions. German Journal of Human Resource Management, 33(3), 249-279.

Heinitz, K., \& Rowold, J. (2007). Gütekriterien einer deutschen adaptation des transformational leadership inventory (TLI) von Podsakoff. Zeitschrift für Arbeits-und Organisationspsychologie, 51(1), 1-15.

Herrero, I. (2018). How familial is family social capital? Analyzing bonding social capital in family and nonfamily firms. Family Business Review, 31(4), 441-459.

Hoffman, B. J., Bynum, B. H., Piccolo, R. F., \& Sutton, A. W. (2011). Person-organization value congruence: How transformational leaders influence work group effectiveness. Academy of Management Journal, 54(4), 779-796.

Jiménez, M. C. R., Martos, M. C. V., \& Jiménez, R. M. (2015). Organisational harmony as a value in family businesses and its influence on performance. Journal of Business Ethics, 126(2), 259-272.

Kellermanns, F. W., Eddleston, K. A., Barnett, T., \& Pearson, A. (2008). An exploratory study of family member characteristics and involvement: Effects on entrepreneurial behavior in the family firm. Family Business Review, 21(1), 1-14.

Kidwell, R., Eddleston, K., \& Kellermanns, F. (2018). Learning bad habits across generations: How negative imprints affect human resource management in the family firm. Human Resource Management Review, 28(1), 1-102.

Klein, S. B., Astrachan, J. H., \& Smyrnios, K. X. (2005). The F-PEC scale of family influence: Construction, validation, and further implication for theory. Entrepreneurship Theory and Practice, 29(3), 321-339.

Kooij, D., \& Boon, C. (2018). Perceptions of HR practices, person-organisation fit, and affective commitment: The moderating role of career stage. Human Resource Management Journal, 28(1), 61-75.

Kosmidou, V., \& Ahuja, M. K. (2019). A configurational approach to family firm innovation. Family Business Review, 32(2), 154-173.

Krappe, A., Goutas, L., \& von Schlippe, A. (2011). The "family business brand": an enquiry into the construction of the image of family businesses. Journal of Family Business Management, 1(1), 37-46.

Krishnan, V. R. (2005). Leader-member exchange, transformational leadership, and value system. Electronic Journal of Business Ethics and Organization Studies.

Kristof, A. L. (1996). Person-organization fit: An integrative review of its conceptualizations, measurement, and implications. Personnel Psychology, 49(1), 1-49.

Kristof-Brown, A. L., Zimmerman, R. D., \& Johnson, E. C. (2005). Consequences of individuals' fit at work: A meta-analysis of person-job, person-organization, person-group, and personsupervisor fit. Personnel Psychology, 58(2), 281-342.

Lajoie, D., Boudrias, J., Rousseau, V., \& Brunelle (2017). Value congruence and tenure as moderators of transformational leadership effects. Leadership \& Organization Development Journal, $38(2), 254-269$. 
Lavelle, J. J., Brockner, J., Konovsky, M. A., Price, K. H., Henley, A. B., Taneja, A., \& Vinekar, V. (2009). Commitment, procedural fairness, and organizational citizenship behavior: A multifoci analysis. Journal of Organizational Behavior: The International Journal of Industrial, Occupational and Organizational Psychology and Behavior, 30(3), 337-357.

Leana, C. R., \& Van Buren, H. J. (1999). Organizational social capital and employment practices. Academy of Management Review, 24(3), 538-555.

Madison, K., Kellermanns, F. W., \& Munyon, T. P. (2017). Coexisting agency and stewardship governance in family firms: An empirical investigation of individual-level and firm-level effects. Family Business Review, 30(4), 347-368.

Meglino, B. M., \& Ravlin, E. C. (1998). Individual values in organizations: Concepts, controversies, and research. Journal of Management, 24(3), 351-389.

Melin, L., Nordqvist, M., \& Sharma, P. (Eds.). (2013). The Sage handbook of family business. Thousand Oaks, CA: Sage.

Meyer, J. P., \& Herscovitch, L. (2001). Commitment in the workplace: Toward a general model. Human Resource Management Review, 11(3), 299-326.

Meyer, J. P., Stanley, D. J., Herscovitch, L., \& Topolnytsky, L. (2002). Affective, continuance, and normative commitment to the organization: A meta-analysis of antecedents, correlates, and consequences. Journal of Vocational Behavior, 61(1), 20-52.

Meyer, J. P., Stanley, D. J., Jackson, T. A., McInnis, K. J., Maltin, E. R., \& Sheppard, L. (2012). Affective, normative, and continuance commitment levels across cultures: A meta-analysis. Journal of Vocational Behavior, 80(2), 225-245.

Miller, D., \& Breton-Miller, L. (2006). Family governance and firm performance: Agency, stewardship, and capabilities. Family Business Review, 19(1), 73-87.

Minichilli, A., Brogi, M., \& Calabrò, A. (2016). Weathering the storm: Family ownership, governance, and firm performance through the financial and economic crisis. Corporate Governance: An International Review, 24, 552-568.

Mitchell, R., Parker, V., Giles, M., Joyce, P., \& Chiang, V. (2012). Perceived value congruence and team innovation. Journal of Occupational and Organizational Psychology, 85(4), 626-648.

Mullins, F. (2018). A Piece of the Pie? The Effects of Familial Control Enhancements on the Use of Broad-Based Employee Ownership Programs in Family Firms. Human Resource Management, 57(5), 979-992.

Nahapiet, J., \& Ghoshal, S. (1998). Social capital, intellectual capital, and the organizational advantage. Academy of Management Review, 23(2), 242-266.

O’Boyle, E. H., Pollack, J. M., \& Rutherford, M. W. (2012). Exploring the relation between family involvement and firms' financial performance: A meta-analysis of main and moderator effects. Journal of Business Venturing, 27, 1-18.

O'Reilly, C. A., Chatman, J., \& Caldwell, D. F. (1991). People and organizational culture: A profile comparison approach to assessing person-organization fit. Academy of Management Journal, 34(3), 487-516.

Parada, M. J., \& Dawson, A. (2017). Building family business identity through transgenerational narratives. Journal of Organizational Change Management, 30(3), 344-356.

Payne, G. T. (2018). Reflections on family business research: Considering domains and theory. Family Business Review, 31(2), 167-175. 
Pearson, A. W., Carr, J. C., \& Shaw, J. C. (2008). Toward a theory of familiness: A social capital perspective. Entrepreneurship Theory and Practice, 32(6), 949-969.

Podsakoff, P. M., MacKenzie, S. B., \& Bommer, W. H. (1996). Transformational leader behaviors and substitutes for leadership as determinants of employee satisfaction, commitment, trust, and organizational citizenship behaviors. Journal of Management, 22(2), 259-298.

Podsakoff, P. M., MacKenzie, S. B., \& Podsakoff, N. P. (2012). Sources of method bias in social science research and recommendations on how to control it. Annual Review of Psychology, 63, 539-569.

Podsakoff, P. M., MacKenzie, S. B., Moorman, R. H., \& Fetter, R. (1990). Transformational leader behaviors and their effects on followers' trust in leader, satisfaction, and organizational citizenship behaviors. The Leadership Quarterly, 1(2), 107-142.

Podsakoff, P. M., \& Organ, D. W. (1986). Self-reports in organizational research: Problems and prospects. Journal of Management, 12(4), 531-544.

Pötschke, I. (2018). Supplementing Q-method with narratives: Contextualizing CEOs' values for family firms. Journal of Management \& Organization, 1-25.

Rau, S., Schneider-Siebke, V., \& Günther, C. (2019). Family Firm Values Explaining Family Firm Heterogeneity. Family Business Review, 32(2), 195-215.

Rau, S. B., Astrachan, J. H., \& Smyrnios, K. X. (2018). The F-PEC revisited: From the family business definition dilemma to foundation of theory. Family Business Review, 31(2), 200-213.

Riketta, M. (2008). The causal relation between job attitudes and performance: A meta-analysis of panel studies. Journal of Applied Psychology, 93(2), 472-481.

Rokeach, M. (1973). The nature of human values. New York: Free Press.

Rousseau, D. M., Sitkin, S. B., Burt, R. S., \& Camerer, C. (1998). Not so different after all: A cross-discipline view of trust. Academy of Management Review, 23(3), 393-404.

Sackmann, S. A. (2011). Culture and performance. In N. Ashkanasy, C. P. M. Wilderom, \& M. F. Peterson (Eds.), Handbook of organizational culture and climate (pp. 188-224). Thousand Oaks, CA: Sage.

Salamon, S. D., \& Robinson, S. L. (2008). Trust that binds: The impact of collective felt trust on organizational performance. Journal of Applied Psychology, 93(3), 593.

Schein, E. H. (1995). Organizational culture and leadership: A dynamic view. San Francisco: Jossey-Bass.

Schwartz, S. H. (1994). Are there universal aspects in the structure and contents of human values? Journal of Social Issues, 50(4), 19-45.

Sequeira, J., Mueller, S. L., \& McGee, J. E. (2007). The influence of social ties and self-efficacy in forming entrepreneurial intentions and motivating nascent behavior. Journal of Developmental Entrepreneurship, 12(3), 275-293.

Sharma, P. (2004). An overview of the field of family business studies: Current status and directions for the future. Family Business Review, 17(1), 1-36.

Sirmon, D. G., \& Hitt, M. A. (2003). Managing resources: Linking unique resources, management, and wealth creation in family firms. Entrepreneurship Theory and Practice, 27(4), 339358.

Sorenson, R. L. (2013). How moral and social values become embedded in family firms. Journal of Management, Spirituality \& Religion, 10(2), 116-137. 
Sorenson, R. L. (2014). Values in family business. In L. Melin, M. Nordqvist, \& P. Sharma (Eds.), The Sage handbook of family business (pp. 463-479). Thousand Oaks, CA: Sage.

Stanley, D., \& Meyer, J. (2016). Employee commitment and performance. In J. Meyer (Ed.), Handbook of employee commitment (pp. 208-221). Cheltenham, UK: Edward Elgar.

Sundaramurthy, C. (2008). Sustaining trust within family businesses. Family Business Review, 21(1), 89-102.

VanVoorhis, C. W., \& Morgan, B. L. (2007). Understanding power and rules of thumb for determining sample sizes. Tutorials in Quantitative Methods for Psychology, 3(2), 43-50.

Vallejo-Martos, M. C. (2011). The organizational culture of family firms as a key factor of competitiveness. Journal of Business Economics and Management, 12(3), 451-481.

Vallejo-Martos, M. C., \& Puentes-Poyatos, R. (2014). Family firms as incubators for ethical behavior: An exploratory study from the perspective of stewardship theory. Journal of Management \& Organization, 20(6), 784-807.

Vandenberghe, C., Bentein, K., \& Stinglhamber, F. (2004). Affective commitment to the organization, supervisor, and work group: Antecedents and outcomes. Journal of Vocational Behavior, 64(1), 47-71.

Verquer, M. L., Beehr, T. A., \& Wagner, S. H. (2003). A meta-analysis of relations between person-organization fit and work attitudes. Journal of Vocational Behavior, 63(3), 473-489.

Wagner, D., Block, J. H., Miller, D., Schwens, C., \& Xi, G. (2015). A meta-analysis of the financial performance of family firms: Another attempt. Journal of Family Business Strategy, 6, 3-13.

Zahra, S. A., Hayton, J. C., Neubaum, D. O., Dibrell, C., \& Craig, J. (2008). Culture of family commitment and strategic flexibility: The moderating effect of stewardship. Entrepreneurship Theory and Practice, 32(6), 1035-1054.

Zwack, M., Kraiczy, N. D., von Schlippe, A., \& Hack, A. (2016). Storytelling and cultural family value transmission: Value perception of stories in family firms. Management Learning, 47(5), 590-614. 